\title{
PENGARUH MOTIVASI KERJA TERHADAP KINERJA PADA PEGAWAI PUSKESMAS
}

\author{
P. Ayu Asri Wulandari', I W. Bagia ${ }^{2}$ \\ 1,2 Jurusan Manajemen, Universitas Pendidikan Ganesha, Singaraja \\ e-mail: wulandariasrio@gmail.com, wayan.bagia@undiksha.ac.id
}

\begin{abstract}
Abstrak
Penelitian ini bertujuan untuk memperoleh penjelasan eksplanatif yang teruji mengenai pengaruh motivasi kerja terhadap kinerja pegawai pada Puskesmas Seririt III. Desain penelitian yang digunakan dalam penelitian ini adalah desain penelitian kuantitatif kausal. Jenis data yang digunakan adalah data primer dan dikumpulkan dengan metode kuesioner. Subjek penelitian ini adalah seluruh pegawai Puskesmas Seririt III yang berjumlah 32 orang, sehingga penelitian ini termasuk kategori penelitian populasi. Data yang diperoleh dianalisis menggunakan analisis regresi linier sederhana. Hasil penelitian menunjukkan ada pengaruh positif dari motivasi kerja terhadap kinerja pegawai pada Puskesmas Seririt III. Berdasarkan koefisien determinasi, motivasi kerja mempengaruhi kinerja sebesar $68,8 \%$ dan sisanya sebesar $31,2 \%$ dipengaruhi oleh variabel lain yang tidak diteliti dalam penelitian ini.
\end{abstract}

Kata kunci: kinerja pegawai dan motivasi kerja

\section{Abstract}

This research aimed to obtain a tested explanative explanation of the effect of work motivation on the employee performance at Puskesmas Seririt III. The research design used in this study is causal quantitative research design. The type of data used is primary data and collected by a questionnaire method. The subject of this study were all the employees of the Puskesmas Seririrt III totally 32 people, so this research was included in the population research category. The data collected was analyzed by simple linear regression analysis. The result showed there was a positive effect of work motivation on the employees performance at Puskesmas Seririt III. Based on the coefficient of determination, work motivation affect employees performance by $68,8 \%$ and $31,2 \%$ were affected by other variables are not examine in this research.

Keywords : employee performance and work motivation

\section{Pendahuluan}

Setiap organisasi pasti selalu mengupayakan berbagai cara untuk mencapai tujuan yang diinginkan organisasi tersebut. Dalam mencapai tujuan diperlukan sumber daya manusia yang berperan aktif sebagai penggerak dalam suatu organisasi karena sumber daya manusia merupakan otak yang dapat merencanakan serta melakukan kegiatan organisasi sehingga sebagai penentu dalam mewujudkan tujuan organisasi. Hal ini dipertegas oleh Hasibuan (2002:10) yang menyatakan bahwa manusia dalam suatu organisasi selalu berperan aktif dan dominan dalam setiap kegiatan organisasi karena manusia menjadi perencana, pelaku, dan penentu terwujudnya tujuan organisasi. Dalam konteks ini manusia memiliki arti pegawai atau sumber daya manusia dalam organisasi.

Berdasarkan data dari Dinas Kesehatan Kabupaten Buleleng Tahun 2019, kinerja pada Puskesmas Seririt III tergolong dalam kategori kurang baik dengan rata-rata 80,27\%, sedangkan kinerja Puskesmas Seririt I dan Puskesmas Seririt II tergolong dalam kategori cukup baik dengan rata-rata berturut-turut $87,46 \%$ dan $85,61 \%$. Kinerja pelayanan pegawai per dimensi kinerja dengan rata-rata $62,98 \%$ yang berada pada kategori kurang baik, sedangkan dilihat dari kinerja per pegawai yang diobservasi yang berjumlah 10 orang, ratarata kinerjanya $75,58 \%$ berada pada kategori kurang baik. Kedisiplinan pegawai juga dinilai rendah ini dilihat dari pegawai yang datang terlambat dan terkadang ada pegawai yang meninggalkan tempat kerja pada saat puskesmas masih jam buka, serta pulang mendahului jam tutup puskesmas. Selanjutnya, pengelolaan arsip juga dinilai kurang baik. Permasalahan lainnya yaitu kurangnya respon masyarakat terhadap kegiatan/program yang diselenggarakan oleh puskesmas menyebabkan kepuasan kerja pegawai menjadi rendah. 
Jumlah pegawai yang kurang memadai mengakibatkan beban kerja fisik pegawai cukup tinggi.

Kinerja merupakan suatu hasil kerja yang dicapai oleh seseorang dalam melaksanakan tugas yang dibebankan kepadanya berdasarkan atas kecakapan, pengalaman, dan kesungguhan, serta waktu (Hasibuan, 2002). Dalam mengukur kinerja menggunakan 3 dimensi dan beberapa indikator diantaranya, 1) dimensi hasil kerja dengan indikator kuantitas, kualitas, dan efisiensi; 2) dimensi perilaku kerja dengan indikator inisiatif, disiplin kerja dan ketelitian; serta 3) dimensi kematangan pribadi dengan indikator kejujuran dan kreativitas (Wirawan, 2009:80).

Rendahnya kinerja pegawai diduga disebabkan oleh rendahnya motivasi pegawai. Motivasi sebagai daya penggerak dari dalam individu untuk melakukan pekerjaan tertentu guna mencapai tujuan yang diinginkan (Busro, 2018:51). Adapun dalam mengukur motivasi digunakan dimensi motivasi kerja menurut teori dua faktor Herzberg (Ivancevich, et al., 2002:154-155) yaitu faktor intrinsik (motivator) dan ekstrinsik (hygiene). Namun, dalam penelitian ini hanya menggunakan dimensi faktor intrinsik karena faktor ini dapat memacu seseorang untuk bekerja lebih baik dan bergairah serta membentuk motivasi yang kuat. Indikator motivasi faktor intrinsik menurut Herzberg yang dikutip oleh Luthans (2011:160) diantaranya keberhasilan (achievement), pengakuan (recognition), tanggung jawab (responsibility), pekerjaan itu sendiri (work it self), serta pengembangan (advancement).

Berdasarkan observasi awal yang dilakukan, ditemukan bahwa motivasi pegawai Puskesmas Seririt III termasuk dalam golongan rendah. Penyebab dari hal tersebut karena beberapa pegawai mengaku mendapat insentif masih dibawah Upah Minimum Kabupaten yang berlaku di Kabupaten Buleleng tahun 2019 yaitu Rp 2.338.850. Rendahnya insentif pegawai berdasarkan beban kerja menyebabkan pegawai berusaha untuk mendapatkan uang tambahan, akibatnya tugas pelayanan ditinggalkan untuk memenuhi kebutuhan tersebut. Hal ini didukung oleh hasil wawancara terhadap pegawai bahwa gaji yang diterima pegawai belum mampu memenuhi kebutuhan keluarga. Begitupula dengan kondisi lingkungan kerja yang masih kurang nyaman bagi pegawai karena ruangan yang tidak dilengkapi dengan AC, ruang tata usaha yang sempit, serta fasilitas laboratorium yang belum lengkap.

Berdasarkan wawancara yang dilakukan terhadap beberapa pasien, pasien mengeluh terhadap lamanya waktu menunggu untuk mendapatkan pelayanan, pelayanan yang kurang ramah, dan kemampuan komunikasi yang kurang baik.

Motivasi kerja tiap individu tidak sama, maka dari itu hal ini harus diperhatikan oleh atasab untuk selalu mengupayakan pegawainya agar memiliki motivasi kerja yang tinggi karena motivasi kerja yang tinggi sangat penting untuk meningkatkan kinerja pegawai. Menurut Gagne (2005) dan Tuan (2011), berpendapat bahwa motivasi kerja karyawan merupakan hal penting yang harus diperhatikan para pimpinan perusahaan, karena motivasi kerja berpengaruh besar dalam meningkatkan kinerja karyawan.

Pimpinan dalam suatu organisasi berperan penting dalam meningkatkan motivasi kerja pegawai. Namun tanpa dibarengi oleh kesadaran semua anggota organisasi, motivasi kerja tidak akan bisa ditingkatkan maupun dipertahankan. Motivasi akan berdampak pada kinerja pegawai, baik itu berdampak ke arah yang positif maupun berdampak ke arah negatif. Jadi dapat disimpulkan bahwa, jika motivasi kerja pegawai rendah, kegairahan ataupun ketekunan pegawai dalam bekerja juga akan mengalami penurunan dimana hal tersebut dapat menurunkan kinerja, sebaliknya jika motivasi kerja pegawai tinggi, pegawai cenderung lebih bersemangat dan tekun dalam melakukan pekerjaannya sehingga kinerja pegawai mengalami peningkatan.

Suatu organisasi dikatakan berhasil jika kinerja pegawainya sesuai dengan yang diharapkan oleh organisasi. Kinerja pegawai dipengaruhi oleh motivasi kerja. Tambunan (2002) mengemukakan bahwa salah satu aspek yang dapat meningkatkan kinerja adalah motivasi yang kuat. Motivasi yang kuat dapat meningkatkan kinerja pegawai. Hal ini didukung oleh teori Kasmir (2016:191) bahwa, semakin termotivasi seseorang untuk melakukan suatu pekerjaan maka kinerjanya akan meningkat. Kedua pendapat ahli tersebut didukung oleh hasil penelitian empirik yang dilakukan oleh Amalia dan Fakhri (2016) yang 
mengungkapkan bahwa motivasi berpengaruh positif dan signifikan terhadap kinerja karyawan.

Penelitian ini memiliki tujuan untuk memperoleh penjelasan eksplanatif tentang pengaruh motivasi kerja terhadap kinerja pegawai pada Puskesmas Seririt III. Hasil penelitian ini diharapkan dapat memberikan manfaat berupa manfaat teoretis dan manfaat praktis. Secara teoretis, penelitian ini diharapkan dapat memberikan sumbangan keilmuan khususnya dalam bidang Manajemen Sumber Daya Manusia mengenai motivasi kerja dan kinerja serta dapat digunakan sebagai kajian teoretis untuk penelitian selanjutnya. Secara praktis, penelitian ini diharapkan dapat memberikan implikasi bagi pihak Puskesmas Seririt III mengenai pentingnya motivasi kerja agar terwujudnya peningkatan kinerja sehingga tujuan organisasi dapat tercapai.

\section{Metode}

Desain penelitian yang digunakan pada penelitian ini adalah desain penelitian kuantitatif kausal. Variabel bebas dalam penelitian ini adalah motivasi kerja $(X)$ sedangkan variabel terikat yang digunakan adalah kinerja $(\mathrm{Y})$. Langkah-langkah metode penelitian kuantitatif kausal adalah sebagai berikut: a) mengidentifikasi masalah, b) membatasi dan merumuskan permasalahan secara jelas, c) melakukan studi pustaka yang berkaitan dengan permasalahan penelitian, d) merumuskan hipotesis/dugaan jawaban sementara, e) merancang metode dan teknik analisis data penelitian yang hendak digunakan, f) mengumpulkan dan menganalisis data, dan g) menarik kesimpulan serta menyusun laporan.

Subjek dalam penelitian ini adalah pegawai Puskesmas Seririt III, sedangkan yang menjadi objek dalam penelitian ini adalah motivasi kerja dan kinerja pegawai pada Puskesmas Seririt III. Populasi dalam penelitian ini adalah seluruh pegawai Puskesmas Seririt III yang berjumlah 32 orang.

Jenis data dalam penelitian ini adalah data kuantitatif. Adapun sumber data dalam penelitian ini adalah data primer dan data sekunder. Data primer dalam penelitian ini bersumber dari kepala puskesmas dan pegawai, seperti hasil wawancara langsung terhadap Kepala Puskesmas Seririt III, Penanggung jawab Jaringan Pelayanan Puskesmas dan Jejaring Fasyankes Puskesmas Seririt III, Pegawai Puskesmas Seririt III, Kasubag Tata Usaha Puskesmas Seririt III serta beberapa pasien Puskesmas Seririt III dan hasil pengisian kuesioner. Data yang didapat berupa permasalahan motivasi yang bersumber dari Pegawai Puskesmas Seririt III serta kepuasan pelayanan puskesmas yang bersumber dari pasien Puskesmas Seririt III. Sedangkan permasalahan lainnya seperti kendala SDM yang dihadapi pegawai Puskesmas Seririt III, kinerja, serta kepuasan kerja bersumber dari hasil wawancara dengan Kepala Puskesmas, Kasubag Tata Usaha, dan Penanggung jawab Jaringan Pelayanan Puskesmas serta Jejaring Fasyankes. Sedangkan data sekunder diperoleh dari Dinas Kesehatan Kabupaten Buleleng yaitu data penilaian kinerja puskesmas Kecamatan Seririt tahun 2019 dan dari Kasubag Tata Usaha Puskesmas Seririt III yaitu arsip yang dimiliki oleh organisasi/instansi seperti struktur organisasi, data penilaian kinerja pegawai fungsional Puskesmas Seririt III berdasarkan perilaku kerja tahun 2019, data kepegawaian Puskesmas Seririt III.

Metode pengumpulan data yang digunakan dalam penelitian ini adalah kuesioner. Kuesioner merupakan alat pengumpulan data secara tertulis yang berisi daftar pertanyaan atau pernyataan yang disusun dan digunakan untuk mengumpulkan informasi yang dibutuhkan dan cocok untuk dianalisis (Babbie, 1986:558). Metode pengumpulan data kuesioner akan menggunakan instrumen angket. Angket digunakan untuk mendapatkan data tentang kinerja dan motivasi pegawai Puskesmas Seririt III, dengan prosedur: (a) membagikan kuesioner, (b) responden diminta mengisi kuesioner pada lembar jawaban yang telah disediakan sambil ditunggu hasilnya, (c) lembar kuesioner dikumpulkan, diseleksi, disortir, diolah, dan kemudian dianalisis. Jawaban tersebut akan ditentukan skornya berupa skala ordinal, dimana jawaban pertanyaan diberi skor dengan menggunakan skala Likert. Instrumen penelitian ini terlebih dahulu diuji validitas dan reliabilitasnya agar dapat memperoleh keakuratan data. 
Penelitian ini menggunakan metode analisis regresi linier sederhana. Teknik analisis data dalam penelitian ini menggunakan bantuan program Statistical Product and Service Solutions (SPSS) versi 16.0 for Windows. Sedangkan teknik analisis data dalam penelitian ini dilakukan dengan langkah-langkah yaitu, 1) menyebarkan kuesioner yang telah valid, 2) melakukan tabulasi data ordinal, 3) mengubah data ordinal ke interval, 4) memasukkan total jumlah data per variabel ke sistem untuk di uji, 5) data tersebut dianalisis menggunakan bantuan program SPSS, dan 6) menginterpretasikan hasil uji yang diperoleh serta menarik suatu simpulan dalam penelitian.

\section{Hasil dan Pembahasan}

Hasil perhitungan analisis regresi linier sederhana yang diperoleh dengan bantuan program komputer Statistical Product and Service Solutions (SPSS) versi 16.0 for Windows dapat dilihat pada tabel 1.

Tabel 1. Hasil Analisis Regresi Linier Sederhana

\begin{tabular}{|c|c|c|c|c|c|}
\hline Parameter & Koefisien & $p$-value & alpha $(\alpha)$ & Keputusan & Simpulan \\
\hline Ryx & 0,829 & 0,000 & 0,05 & Menolak $\mathrm{H}_{0}$ & $\begin{array}{l}\text { Ada hubungan antara } \\
\text { motivasi kerja dengan kinerja }\end{array}$ \\
\hline$R^{2} y x$ & 0,688 & 0,000 & 0,05 & Menolak $\mathrm{H}_{0}$ & $\begin{array}{l}\text { motivasi kerja terhadap } \\
\text { kinerja adalah } 68,8 \%\end{array}$ \\
\hline Pyع & 0,312 & - & - & - & $\begin{array}{l}\text { Besar sumbangan pengaruh } \\
\text { faktor lain terhadap kinerja } \\
\text { adalah } 31,2 \%\end{array}$ \\
\hline$\alpha$ & 12,549 & 0,000 & 0,05 & Signifikan & Bisa memprediksi \\
\hline$\beta$ & 0,276 & 0,000 & 0,05 & Signifikan & Bisa memprediksi \\
\hline
\end{tabular}


Hasil persamaan regresi yang diperoleh yaitu nilai konstanta $(\alpha)$ sebesar 12,549 dan nilai koefisien regresi motivasi kerja $(\beta)$ sebesar 0,276 . Dari persamaan di atas dapat dijelaskan sebagai berikut.

(1) Konstanta sebesar 12,549 mengandung arti bahwa apabila motivasi kerja nilainya konstan atau sama dengan nol, maka rata-rata nilai kinerja pegawai sebesar 12,549.

(2) Nilai koefisien motivasi kerja $(\beta)$ sebesar 0,276 berpengaruh secara parsial terhadap kinerja pegawai. Hal ini mengandung arti bahwa setiap kenaikan motivasi kerja satu satuan maka variabel kinerja pegawai mengalami kenaikan sebesar 0,276, sehingga menjadi 12,549 dengan asumsi bahwa variabel bebas yang lainnya tetap atau bernilai konstan.

(3) Nilai koefisien (Pyع) sebesar 0,312 memiliki arti ada hubungan pengaruh dari variabel lain sebesar $31,2 \%$ yang tidak diteliti dalam penelitian ini.

Pengujian hipotesis dalam penelitian ini menggunakan uji parsial (uji t). Uji parsial (uji t) dapat dilihat dari hasil uji regresi linier sederhana menunjukkan bahwa variabel motivasi kerja mempunyai nilai signifikansi sebesar 0,000 yang artinya $p$-value $0,000<\alpha=0,05$, maka dapat dinyatakan bahwa motivasi kerja berpengaruh terhadap kinerja pegawai. Nilai $t$ positif menunjukkan bahwa variabel motivasi kerja mempunyai hubungan yang searah dengan kinerja. Jadi dapat disimpulkan bahwa hipotesis diterima yaitu motivasi kerja berpengaruh positif terhadap kinerja.

Berdasarkan hasil penelitian, diperoleh bahwa motivasi kerja berpengaruh terhadap kinerja pegawai pada Puskesmas Seririt III. Pegawai yang memiliki motivasi kerja yang tinggi akan cenderung berkinerja dengan lebih baik dibanding dengan pegawai yang memiliki motivasi yang rendah. Keberadaan motivasi pada setiap pegawai mampu menghasilkan kinerja yang baik pada organisasi tempatnya bekerja. Ciri-ciri pegawai yang memiliki motivasi kerja yang tinggi diantaranya menyukai tantangan dalam pekerjaan, bertanggungjawab atas pekerjaannya, selalu berusaha untuk menghasilkan kuantitas dan kualitas hasil kerja melebihi target yang ditetapkan, memiliki inisiatif, menghargai kesempatan mendapat promosi jabatan dan memperoleh pendidikan serta pelatihan.

Berdasarkan penelitian yang telah dilakukan, maka diperoleh temuan bahwa variabel motivasi kerja berpengaruh positif terhadap kinerja pegawai pada Puskesmas Seririt III. Hasil penelitian ini mendukung teori yang disampaikan oleh Kasmir (2016:191) bahwa semakin termotivasi seseorang untuk melakukan suatu pekerjaan maka kinerjanya akan meningkat serta hasil penelitian empirik yang dilakukan oleh Amalia dan Fakhri (2016) yang mengungkapkan bahwa motivasi berpengaruh positif dan signifikan terhadap kinerja karyawan. Motivasi kerja pegawai sangat penting untuk dipahami oleh pimpinan organisasi karena sangat menentukan kinerja pegawai tersebut. Pimpinan hendaknya memperhatikan pegawainya agar terus termotivasi dan menemukan cara untuk meningkatkan maupun mempertahankan rasa motivasi pada diri pegawainya. Pegawai yang memiliki motivasi kerja tinggi akan menyebabkan kinerja mereka lebih meningkat.

Keterbatasan penelitian ini yaitu variabel bebas yang diteliti pengaruhnya terhadap kinerja hanya dibatasi pada variabel motivasi kerja sedangkan masih banyak variabel lain yang diduga kuat dapat berpengaruh terhadap kinerja. Populasi dalam penelitian ini juga masih belum maksimal karena hanya menggunakan pegawai yang ada pada satu instansi saja sehingga hasil penelitian belum bisa untuk dijadikan simpulan umum pada instansi lain sehingga diharapkan bagi peneliti selanjutnya untuk menggunakan perusahaan yang lebih besar dengan populasi penelitian yang lebih luas agar hasil penelitian lebih teruji keandalannya. Terdapat keterbatasan penelitian dengan menggunakan kuesioner dimana terkadang jawaban yang diberikan oleh responden tidak menunjukkan keadaan yang sebenarnya.

Hasil penelitian ini diharapkan dapat menambah pengetahuan dan wawasan mengenai motivasi kerja dan kinerja serta memberikan masukan kepada Puskesmas Seririt III dalam meningkatkan kinerja pegawainya. Ketika organisasi tidak mampu dalam menumbuhkan rasa motivasi pada diri pegawai akan berakibat pada penurunan kinerja pegawai maupun 
organisasi. Maka dari itu, dibutuhkan langkah yang tepat untuk meningkatkan kinerja pegawai.

Langkah-langkah yang bisa dilakukan oleh pimpinan Puskesmas Seririt III dalam meningkatkan kinerja pegawainya adalah dengan selalu memperhatikan kebutuhan pegawainya agar senantiasa termotivasi dalam bekerja. Pimpinan hendaknya menilai motivasi pegawainya secara berkala dengan melakukan wawancara langsung dengan pegawai. Wawancara ini hendaknya dilakukan dengan memberi kebebasan pegawai untuk berpendapat mengenai apa yang sebaiknya dilakukan pimpinan untuk meningkatkan motivasi pegawai di lingkup organisasi. Pendapat yang diutarakan oleh pegawai di masingmasing bidang hendaknya dipikirkan lagi oleh pimpinan yang nantinya pimpinan bertanggungjawab untuk memutuskan kebijakan sesuai dengan hal yang paling banyak diinginkan untuk meningkatkan motivasi pegawai. Langkah lain yang dapat dilakukan untuk meningkatkan kinerja adalah meningkatkan kepuasan kerja. Pimpinan hendaknya memperhatikan kepuasan kerja pegawainya melalui pemberian insentif uang dan/atau nonuang, promosi jabatan, membina hubungan yang baik dengan semua pegawai, memperhatikan kenyamanan lingkungan kerja, serta memberikan kesempatan pegawai untuk mendapatkan pendidikan dan pelatihan.

\section{Simpulan dan Saran}

Berdasarkan penelitian dan pengujian hipotesis yang telah dilakukan, maka diperoleh temuan bahwa variabel motivasi kerja berpengaruh positif terhadap kinerja pegawai pada Puskesmas Seririt III. Hal ini menunjukkan bahwa semakin baik variabel motivasi kerja itu diterapkan maka semakin meningkat pula efektivitas dari variabel kinerja. Motivasi kerja memiliki peranan dalam mempengaruhi kinerja pegawai menuju lebih baik dan searah, yaitu jika motivasi kerja naik maka kinerja pun akan meningkat, sebaliknya jika motivasi kerja turun maka kinerja pun akan mengalami penurunan.

Berdasarkan hasil pembahasan dan simpulan, maka diusulkan beberapa saran diantaranya: (1) bagi pihak Puskesmas Seririt III, diharapkan untuk lebih memperhatikan tingkat motivasi pegawai karena tanpa adanya motivasi, kinerja pegawai tidak akan mencapai hasil maksimal. Pemberian motivasi ini dapat dilakukan dengan cara memberikan penghargaan dalam bentuk insentif ataupun tambahan penghasilan kepada pegawai sesuai dengan beban kerjanya. Di samping itu, motivasi dapat ditingkatkan dengan memberikan kesempatan pada seluruh pegawai, terutama jabatan fungsional untuk memperoleh pendidikan dan pelatihan seperti diklat berbasis kompetensi. Diklat ini sangat terbatas, sehingga diharapkan pimpinan Puskesmas Seririt III mampu untuk menyesuaikan jadwal pegawainya untuk bergilir mengikuti diklat tersebut. Pegawai yang dikirim untuk diklat ini diharapkan sesuai dengan latar belakang keahlian yang dibutuhkan, bukan karena dipilih atas unsur kedekatan dengan pimpinan. (2) Bagi peneliti selanjutnya diharapkan untuk mengembangkan penelitian ini dengan menggunakan populasi ataupun sampel yang lebih luas serta menguji variabel lain yang juga memiliki pengaruh kuat terhadap kinerja pegawai seperti pengetahuan, kepemimpinan, budaya organisasi, komitmen organisasi, dan disiplin kerja.

\section{Daftar Pustaka}

Amalia, Syarah dan Fakhri, Mahendra. 2016. Pengaruh Motivasi Kerja Terhadap Kinerja Karyawan Pada PT. Gramedia Asri Media Cabang Emerald Bintaro. Jurnal Computech dan Bisnis. Vol. 10, No. 2 (hlm. 119-127).

Babbie. 1986. The Practice of Social Research. 4th Edition. Belmont: Wadsworth.

Busro, Muhammad. 2018. Teori-teori Manajemen Sumber Daya Manusia. Jakarta: Prenadamedia Group.

Dinas Kesehatan Kabupaten Buleleng. 2019. Penilaian Kinerja Puskesmas di Kabupaten Buleleng Tahun 2019. Singaraja: Dinas Kesehatan Kabupaten Buleleng. 
Gagne, Maryle'ne, et al. 2005. Self-Determination Theory and Work Motivation. Journal of Organizational Behaviour. Vol. 26, No. 3 (hlm. 331-362).

Hasibuan, Malayu S.P. 2002. Manajemen Sumber Daya Manusia Edisi Revisi. Jakarta: PT. Bumi Aksara.

Ivancevich, John M., Robert Konopaske, Michael T. Matteson. 2002. Organizational Behaviour and Management. 7th Edition. Houston: McGraw Hill.

Kasmir. 2016. Manajemen Sumber Daya Manusia (Teori dan Praktik). Jakarta: PT RajaGrafindo Persada.

Luthans, F. 2011. Perilaku Organisasi. Cetakan Keempat. Yogyakarta: ANDI.

Tambunan, T. H. 2002. Usaha Kecil dan Menengah di Indonesia Beberapa Isu Penting. Jakarta: PT. Salemba Empat.

Tuan, Lu Trong. 2011. Convergence of Antecedents on Work Motivation and Work Outcomes. Mediterranean Journal of Social Sciences. Vol. 2, No. 2 (hlm. 54-56).

Wirawan. 2009. Evaluasi Kinerja Sumber Daya Manusia: Teori, Aplikasi, dan Penelitian. Jakarta: Salemba Empat. 